\title{
68. An Early Late Oligocene Age indicated by Diatoms for a Primitive Desmostylian Mammal Behemotops from Eastern Hokkaido, Japan
}

\author{
By Tsunemasa SAIto, *) John A. BARron,**) and Masamichi SAKAmoto*) \\ (Communicated by Teiichi Kobayashi, M. J. A., Nov. 14, 1988)
}

Desmostylians are a unique group of amphibious mammals characterized by their distinct teeth, each of which consists of a number of cusps that developed as closely packed enamel cylinders. They occur only in upper Oligocene and Miocene strata and are restricted to the margins of the North Pacific Ocean. In Japan, three genera Desmostylus, Desmostylella and Paleoparadoxia, constituted important elements of coastal marine faunas during an interval from late Early Miocene to early Middle Miocene time (Inuzuka, 1984; Chinzei, 1984). Beginning in the fall of 1976, a series of discoveries of skeletons of primitive desmostylians and cetaceans took place from the Morawan Formation exposed along the banks of the Morawan River, Tokachi Province, eastern Hokkaido (Fig. 1). On the basis of molluscan biostratigraphy, the Kamikawa Group which comprises the Morawan Formation as its middle member, had long been considered to be middle Miocene in age (Mizuno et al., 1969). Matsui (1984) suggested, however, an Oligocene age of the Morawan Formation largely based on two radiometric ages, one $\mathrm{K}-\mathrm{Ar}$ age of $27.4 \pm 1.5 \mathrm{Ma}$ from a tuff layer intercalated within the upper part of the Morawan Formation and another fission-track age of $29.2 \pm 3.3 \mathrm{Ma}$ from a biotite-bearing tuffaceous sandstone of the Honbetsuzawa Formation directly underlying the Morawan Formation. Strengthened by this revised Oligocene age of the desmostylians from the Morawan Formation which would place them the oldest among all the known desmostylians of the Japanese Islands, Inuzuka (1984) concluded that they belonged to a new genus ancestral to all the younger genera.

While this progress was being made in Japan, Domning et al. (1986) were examining primitive desmostylians forming a part of the famed "Emlong Collection" of fossil vertebrates from Oregon and Washington and proposed a new genus Behemotops to represent two most primitive forms, $B$. proteus and $B$. emlongi. After reviewing these North American forms of Behemotops, Inuzuka (1987) agreed that the desmostylians of the Morawan Formation also belong to this genus although they may differ at the species level. These records provide concrete evidence that species of Behemotops lived in northern Japan contemporaneously with their appearances in North America. An important remaining question is the origin of this interesting group of mammals. Did the lineage begin in Asia or western North America? Domning et al. (1986) reported the age of their two species of Behemotops to be "late Oligocene, but not the latest".

We present here a diatom evidence which establishes the age of the Hokkaido Behemotops to be early late Oligocene. Attempts to date biostratigraphically the Mcrawan Formation were rewarded when two calcareous concretions yielded

*) Department of Earth Sciences, Yamagata University, Yamagata 990, Japan.

**) U.S. Geological Survey, Menlo Park, California 94025, U.S.A. 


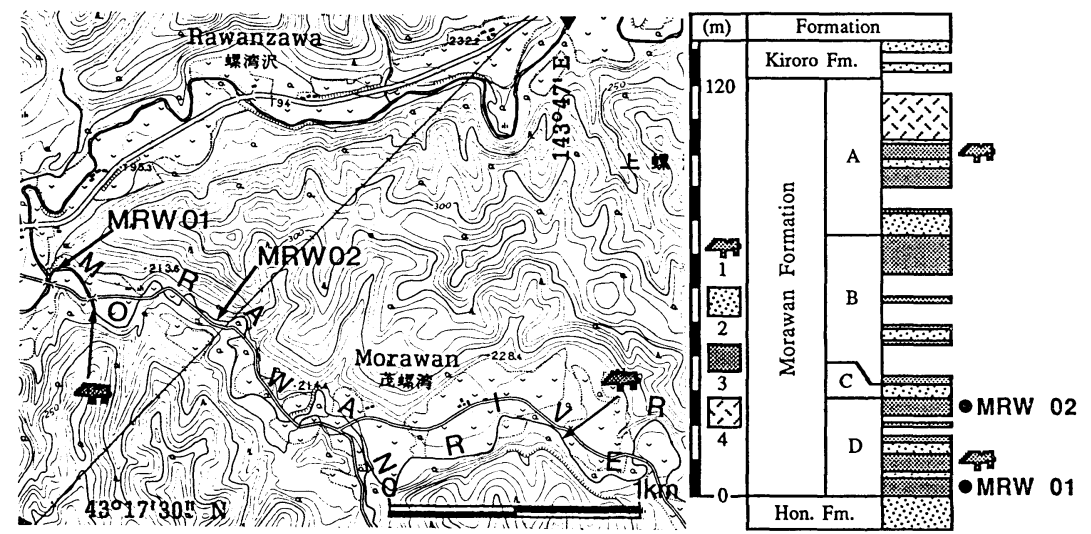

Fig. 1. Index map showing the location of fossil diatoms and the discovery sites of Behemotops along a tributary of the Morawan River, Ashoro Township, Tokachi Province, eastern Hokkaido. Generalized stratigraphic column is also shown. Abbreviations: A, Upper tuffaceous mudstone member; B, Middle hard shale member; C, Kamirawan Sandstone; D, Lower platy shale member. 1, Behemotops bones; 2, sandstone; 3, siltstone and shale; 4, tuffaceous siltstone. Hon. Fm., Honbetsuzawa Formation. Base map after 7.5-minute quadrangle topographic sheet "Kamirawan" at scale of $1: 25,000$.

siliceous microfossils after dissolving these rocks with a hot $\left(60^{\circ} \mathrm{C}\right) 10 \%$ solution of formic acid. These two concretions come from two levels of the Morawan Formation in its lower platy shale facies (Fig. 2).

The siliceous microfossils of the Morawan Formation include both radiolarians and diatoms. Radiolarians are, however, few and rather poorly preserved with the inclusion of only two age-diagnostic species, Artophormis gracilis Riedel and Pterocorys clausus (Popofsky). A. gracilis ranges from the early Oligocene to early Miocene and $P$. clausus has so far been known from the late early Miocene and onwards. Diatoms are better preserved and more abundant than the radiolarians. Of the two diatom assemblages recovered, the flora of MW-02 is better preserved and more diverse than MW-01, although the latter assemblage was probably derived from an MW-02-like assemblage. The MW-02 assemblage is dominated by shelf-dwelling diatoms of the genus Stephanopyxis which resemble late Eocene-early Oligocene assemblages described from the Southern Ocean (Hajos, 1976; Gombos, 1977; Schrader and Fenner, 1976; Gombos and Ciesielski, 1983). The assemblage lacks, however, the genus Pyxilla, an important marker genus that became extinct at the end of the early Oligocene, suggesting a postearly Oligocene age of the flora. The flora contains very rare specimens of Synedra sp. and Thalassiothrix sp., two genera that evolve in the latest early Oligocene. The assemblage does not, however, resemble the late Oligocene flora described from the Bering Sea by Baldauf and Barron (1987). Other characteristic species of the present assemblage are enumerated in Appendix and most of them are illustrated in Fig. 2. Rouxia sp. (Fig. 2, 17-18) is possibly synonymous with the species listed as $R$. elongata in the late Oligocene diatom flora from the Komandorsky Islands (Gladenkov, 1988).

When all the stratigraphic ranges of the taxa present are combined, the age of MW-02 flora is best interpreted to be early late Oligocene. This diatom age suggests that the Hokkaido Behemotops lived closer to the time of Behemotops 


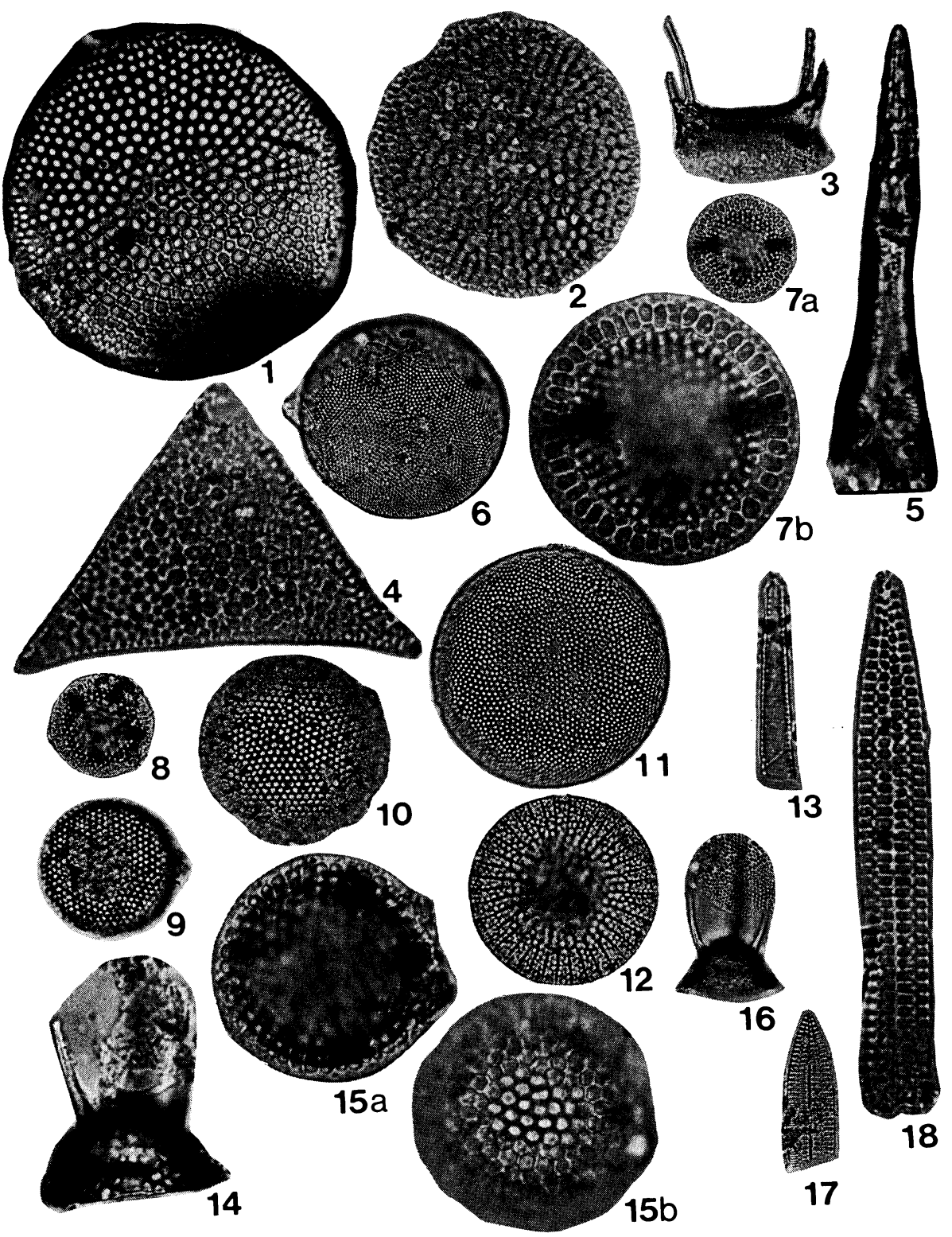

Fig. 2. Representative species of diatom flora from the Morawan Formation. 1-2, Coscinodiscus tuberculatus var. atlantica; 3, Odontella cornuta; 4, Pseudotriceratium radiosoreticulatum; 5, Rhizosolenia antarctica; 6, Stellarima microtrias; 7a, b, Stephanopyxis eocaenica, same specimen; 8, Stephanopyxis petaliforma; 9, Stephanopyxis sp. cf. S. corona; 10, Stephanopyxis spinossima; 11, Thallassiosira sp. cf. T. bukryi; 12, Stictodiscus kittonianus; 13 , Thallassionema sp., fragment; 14, 15a-b, 16, Stephanopyxis superba var. trispinosa; 17, 18, Rouxia sp. ; 14, 16 margin views; $15 \mathrm{a}-\mathrm{b}$, same specimen, low and high focus. $1,2,13,15 a-b, \times 1060 ; 3,6,7 a, 8-12, \times 430 ; 4,5,7 b, 18, \times 1000 ; 14, \times 1670 ; 16$, $\times 560 ; 17, \times 820$. 
proteus from the Pysht Formation of Olympic Peninsula, Washington, than the younger $B$. emlongi from the Central Coast Range, Oregon. Whether the stratigraphic range of $B$. sp. of Hokkaido predated $B$. proteus of the North American coast or they lived contemporaneously but as a separate species cannot be conclusively determined at this time because of the lack of species identification on the part of Hokkaido specimens and of more precise biostratigraphic control on the part of $B$. proteus. This diatom assemblage of late early Oligocene age is the first well-documented record of Paleogene diatom flora in Japan and signifies that diatoms can be useful in biostratigraphic dating of Japanese Paleogene strata.

We express our deep gratitude to Dr. Teiichi Kobayashi, M. J. A., Professor Emeritus of the University of Tokyo, for providing us with facilities to publish this paper. Our gratitudes are also extended to Drs. Catherine A. Nigrini and Annika Sanfilippo for radiolarian analyses and Miss Yoko Misawa for typing and proofreading the manuscript. The work in Japan was supported by a Grantin Aid for Cooperative Research, no. 61304010, provided by the Ministry of Education, Science and Culture of the Government of Japan.

Appendix:-Floral reference list of the diatom species discussed:

Coscinodiscus tuberculatus var. atlantica Gleser and Jouse, 1974, in Jouse, A. P. (ed.), Mikropaleontologija Okeanov i Morej, p. 49-62. -Schrader and Fenner, 1976, loc. cit., p. 972 , pl. 14, fig. 4, pl. 29, figs. 3, 5, 6, 12, 13. Stratigraphic range: middle Eocene to late Oligocene.

Odontella cornuta (Brun) Schrader [=Biddulphia cornuta Brun, 1894], Schrader and Fenner, 1976, loc. cit., p. 992, pl. 20, fig. 5. Range: middle Eocene to late Oligocene.

Pseudotriceratium radiosoreticulatum Grunow, in Schmidt, 1890, Atlas der Diatomaceen-Kunde, Leipzig, pl. 151, figs. 35-36. - Gombos and Ciesielski, 1983, loc. cit., figs. 1-3. Range: late Eocene to early Miocene.

Rhizosolenia antarctica Fenner, 1984, Micropaleontology, vol. 30, p. 333, pl. 2, fig. 5. -Fenner, 1985, loc. cit., p. 736, figs. 11,$12 ; 3$, 4. Range: early Oligocene to late Oligocene.

Stellarima microtrias (Ehrenberg) Hasle and Sims (=Symbolophora microtrias Ehrenberg, 1844), Hasle and Sims 1986, p. 11, figs. 18-27, The diatom genus Stellarima and Symbolophora with comments on the genus Actinoptychus. Br. Phycological Journal, v. 21, p. 97-114. Range: Oligocene (or older)-Recent.

Stephanopyxis eocaenica Hajos, 1976, loc. cit., p. 824, pl. 4, figs. 3, 4. -Gombos and Ciesielski, 1983, loc. cit., p. 605, pl. 10, figs. 8-11. Range: late Eocene to early Oligocene.

Stephanopyxis petaliforma Domatova, p. 254, pl. LXIX, figs. 7-10, in Menner, V. V., ed., 1984, Atlas fauny i flory neogenovkh otlozheniy Dal'nego Vostoka. Tochilinskiy opornyi razrez Zapadnoy Kamchatki: Acad. Nauk SSSR, Geologicheskii Institut, Trudy, vyp. 385,334 pp., 96 pls., and 16 insert figures. Range: late Eocene to middle Miocene.

Stephanopyxis corona (Ehrenberg) Grunow (=Systephania corona Ehrenberg, 1844), Grunow in Van Heurck, 1882, pl. 83, figs. 10-11, Synopsis des Diatomees de Belgique. Atlas, pls. 78-103 (1882). Ducaju et Cie., Anvers. Range: middle Eocene to Miocene.

Stephanopyxis spinossima Grunow, 1884, Denkschrift. Math.-Naturw. Classe Kaiserl. Akad. Wiss., vol. 48, p. 90-91. - Schrader and Fenner, 1976, loc. cit., p. 1000 , pl. 31, fig. 5. Range: late Oligocene to late Miocene.

Stephanopyxis superba var. trispinosa Gombos, 1977, loc. cit., p. 597, pl. 30, figs. 3-6, 9. - Fenner, 1985, in Plankton Stratigraphy, Cambridge Univ. Press, p. 739, 
figs. 12, 3, 3. Range: Eocene to late Oligocene.

Stictodiscus kittonianus Greville, 1861, Microscop. Soc. London, Trans., p. 71, pl. 10, figs. 2, 3. - Schrader and Fenner, 1976, loc. cit., p. 1001, pl. 35, fig. 27. Range: middle Eocene to early Miocene.

Thallassiosira sp. cf. T. bukryi Barron, 1983, Marine Micropal., vol. 7, p. 511, pl. 4, figs. 1, 2, pl. 6, fig. 9. Range: late Eocene to early Miocene.

\section{References}

Baldauf, J. G., and Barron, J. A. (1987) : Bull. U.S. Geol. Surv., 1765, pp. 1-17, pls. 1-14. Chinzei, K. (1984): Assoc. Geol. Collaboration Japan, Monograph 28, pp. 13-23 (in Japanese with English abstract).

Domning, D. P., Ray, C. E., and McKenna, M. C. (1986) : Smithsonian Contr. Paleobiol., 59, 1-56.

Gladenkov, A. Yu. (1988) : Abstracts 10th Internat. Symp. Living \& Fossil Diatoms, Huhmari, Joensuu, Finland.

Gombos, A. M., Jr. (1977) : Init. Rep. DSDP Leg 36, pp. 575-688, pls. 1-42.

Gombos, A. M., Jr., and Ciesielski, P. F. (1983) : Init. Rep. DSDP Leg 71, pt. 2, pp. 583-632, pls. 1-26.

Hajos, M. (1976) : Init. Rep. DSDP Leg 35, pp. 817-884, pls. 1-25.

Inuzuka, N. (1984) : Assoc. Geol. Collaboration Japan, Monograph 28, pp. 1-12 (in Japanese with English abstract).

(1987) : Professor Masaru Matsui Memorial Volume. Sapporo, Japan, pp. 13-26, pls. 1-2 (in Japanese with English abstract).

Matsui, M. (1984) : Geol. Soc. Japan, Abstracts with Programs, 93rd Ann. Meet., p. 348 (in Japanese).

Mizuno, A., Sumi, Y., and Yamaguchi, S. (1969) : Bull. Geol. Surv. Japan, 20, 633-649.

Schrader, H.-J., and Fenner, J. (1976) : Init. Rep. DSDP Leg 38, pp. 921-1100, pls. 1-45. 